\title{
Robotic surgery facilitates complex minimally invasive operations
}

\author{
Ray K. Chihara, Min P. Kim, Edward Y. Chan \\ Division of Thoracic Surgery, Department of Surgery, Weill Cornell Medical College, Houston Methodist Hospital, Houston, TX, USA \\ Correspondence to: Edward Y. Chan, MD, FACS. Assistant Professor of Surgery, Assistant Professor of Cardiothoracic Surgery, Weill Cornell Medical \\ College, Division of Thoracic Surgery, Houston Methodist Hospital, 6550 Fannin Street, Smith Tower, Suite 1661, Houston, TX 77030, USA. \\ Email: eychan@houstonmethodist.org. \\ Provenance and Peer Review: This article was commissioned by the editorial office, fournal of Thoracic Disease. The article did not undergo external peer \\ review. \\ Comment on: Na KJ, Park S, Park IK, et al. Outcomes after total robotic esophagectomy for esophageal cancer: a propensity-matched comparison \\ with hybrid robotic esophagectomy. J Thorac Dis 2019;11:5310-20.
}

Submitted Mar 09, 2020. Accepted for publication May 08, 2020.

doi: 10.21037/jtd-2020-42

View this article at: http://dx.doi.org/10.21037/jtd-2020-42

Robotic surgery continues to become more prevalent and adoption of the technology is evident in many facets of surgery. Robotic esophageal, gastric, pancreatic, colon and rectal resections have increased at a faster pace compared to laparoscopic techniques, and open resections have decreased between 2010 and 2014 (1). The number of articles related to robotic surgery have increased substantially in the past 10 years, indicating ongoing strong interest in the technology. There is overwhelming evidence in the literature supporting improved post-operative recovery and decreased length of stay for minimally invasive operations, therefore there exists a strong push towards performing complex operations using minimally invasive techniques (2). A major reason for the interest in robotic surgery appears related to the facilitation of complex minimally invasive operations.

Conventional minimally invasive techniques, like laparoscopy and thoracoscopy, have limitations in range of motion and dexterity, two-dimensional visualization, and challenging ergonomics. The advent of robotic surgery has allowed technological improvements to range of motion and dexterity, attenuation of tremor, three-dimensional view and superior ergonomics for the surgeon. Robotic surgery may assist in performance of complex operations particularly in thoracic procedures due to the rigid nature of the chest wall, lending further advantages to the available wristed instruments. The adoption of robotic surgery for common operations has been slower where many surgeons have mature experience in advanced laparoscopic skills and the pliable nature of the abdominal wall allows access to most areas of the abdomen using straight instruments (3).

The use of robotic surgery (T-RAMIE) compared to a hybrid laparotomy approach (H-RAMIE) for the abdominal portion of the esophagectomy was evaluated by $\mathrm{Na}$ and colleagues (4). Preparation of the gastric conduit and lymphadenectomy is a critical step for esophagectomy and is technically challenging. There were no statistical differences between robotic and open techniques regarding lymph nodes harvested, anastomotic leaks or other associated complications indicating that the total robotic approach is feasible and safe, albeit within the limitations of a retrospective study. Similar findings have been found in other complex operations performed using robotic surgery compared to open technique for gastric, pancreatic, colon, rectal, lung, prostate and uterine oncologic resections $(1,5-7)$. Comparing clinical outcomes between robotic techniques and conventional laparoscopic or thoracoscopic techniques is difficult methodologically; however, studies have emerged implicating improved clinical outcomes for operations where robotic techniques have matured (6-8).

Complex operations such as esophagectomy, traditionally performed using an open surgical approach, are feasible and safe using robotic techniques. Significant interest in robotic surgery is due to the ability to facilitate completion of complex surgeries using minimally invasive techniques. Further studies are necessary focusing on the facilitation of complex operations while maintaining excellent clinical and oncologic outcomes during this period of increasing adoption, improvement and maturation of robotic surgical 
technology.

\section{Acknowledgments}

Funding: None.

\section{Footnote}

Conflicts of Interest: All authors have completed the ICMJE uniform disclosure form (available at http://dx.doi. org/10.21037/jtd-2020-42). Dr. EYC serves as an unpaid editorial board member of the Fournal of Thoracic Disease from May 2019 to April 2021 and reports personal fees from Veran Medical Technologies, outside the submitted work; Dr. MPK serves as an unpaid editorial board member of the Fournal of Thoracic Disease from Sep 2018 to Aug 2020 and reports personal fees from Veran, personal fees from Intuitive Surgical, personal fees from Medtronic, outside the submitted work. The other author has no conflicts of interest to declare.

Ethical Statement: The authors are accountable for all aspects of the work in ensuring that questions related to the accuracy or integrity of any part of the work are appropriately investigated and resolved.

Open Access Statement: This is an Open Access article distributed in accordance with the Creative Commons Attribution-NonCommercial-NoDerivs 4.0 International License (CC BY-NC-ND 4.0), which permits the noncommercial replication and distribution of the article with the strict proviso that no changes or edits are made and the original work is properly cited (including links to both the formal publication through the relevant DOI and the license). See: https://creativecommons.org/licenses/by-nc-nd/4.0/.

Cite this article as: Chihara RK, Kim MP, Chan EY. Robotic surgery facilitates complex minimally invasive operations. J Thorac Dis 2020;12(9):4606-4607. doi: 10.21037/jtd-2020-42

\section{References}

1. Konstantinidis IT, Ituarte P, Woo Y, et al. Trends and outcomes of robotic surgery for gastrointestinal (GI) cancers in the USA: maintaining perioperative and oncologic safety. Surg Endosc 2019. [Epub ahead of print].

2. Kim MP, Godoy C, Nguyen DT, et al. Preemptive painmanagement program is associated with reduction of opioid prescriptions after benign minimally invasive foregut surgery. J Thorac Cardiovasc Surg 2019. [Epub ahead of print].

3. Kockerling F. Robotic vs. Standard Laparoscopic Technique - What is Better? Front Surg 2014;1:15.

4. Na KJ, Park S, Park IK, et al. Outcomes after total robotic esophagectomy for esophageal cancer: a propensitymatched comparison with hybrid robotic esophagectomy. J Thorac Dis 2019;11:5310-20.

5. Kneuertz PJ, D'Souza DM, Richardson M, et al. LongTerm Oncologic Outcomes After Robotic Lobectomy for Early-stage Non-Small-cell Lung Cancer Versus Videoassisted Thoracoscopic and Open Thoracotomy Approach. Clin Lung Cancer 2020;21:214-24.e2.

6. Du Y, Long Q, Guan B, et al. Robot-Assisted Radical Prostatectomy Is More Beneficial for Prostate Cancer Patients: A System Review and Meta-Analysis. Med Sci Monit 2018;24:272-87.

7. Jin YM, Liu SS, Chen J, et al. Robotic radical hysterectomy is superior to laparoscopic radical hysterectomy and open radical hysterectomy in the treatment of cervical cancer. PLoS One 2018;13:e193033.

8. Soliman BG, Nguyen DT, Chan EY, et al. Robot-assisted hiatal hernia repair demonstrates favorable short-term outcomes compared to laparoscopic hiatal hernia repair. Surg Endosc 2020;34:2495-502. 